\title{
The problems of students' physical training individualization
}

\author{
Druz V.A ${ }^{1}$, Iermakov S.S. ${ }^{2}$, Nosko M.O. ${ }^{3}$, Shesterova L.Ye. ${ }^{1}$, Novitskaya N.A. ${ }^{1}$ \\ ${ }^{1}$ Kharkov State Academy of Physical Culture \\ ${ }^{2}$ Kazimierz Wielki University, Poland \\ ${ }^{3}$ Chernigiv National T.G. Shevchenko Pedagogical University
}

\begin{abstract}
Purpose:

to assess physical health and biological age of 1st 2nd year girl students, depending on their physical activity, as well as to work out system of control over students' health.

Material: $\quad$ in the research 1 st and 2 nd year girl students $(n=120)$ participated.

Results: $\quad$ students' busy in their working day was analyzed as well as student's understanding of healthy life style during working day. We also paid attention to reasons of sharp weakening of students' physical fitness and determined integral indicator of healthy life style conception as well as significance of every its component. The following concepts are introduced: physical health, including individual level of physical condition; physical fitness and physical state. We found normal level for every component of physical health and correlation between population, regional and individual norms.

Conclusions: For students' healthy life style formation it is necessary to observe norm requirements to all its components. Violation of any component's norm results in worsening general final result.
\end{abstract}

Keywords:

norm, physical condition, biological age, chronological age, individual growth.

\section{Introduction}

Progress of higher school is connected with periodic reformation of education, determined by continuous evolution of society, Emersion of new information in every field of knowledge results in re-structuring of educational programs. In its turn it results in reviewing of academic plans and education's structure. Change of equity significance of time for fundamental disciplines is solved at the cost of secondary disciplines. To the largest extent it concerns physical education. Secondary role of this discipline in structure of students' teaching and insufficient understanding significance of students' physical fitness have already resulted in sharp worsening of students' health. Besides, students also do not understand completely significance of normal physical growth and its individual aspects. As a result Ukraine has become one of first in Europe by population mortality.

Refusal from physical culture discipline and testing for physical fitness lead to full loss of control over students' physical condition. Such approach does not permit to correct the required physical loads, which are sufficient for students' health.

In publications, devoted to this age, exclusive significance of physical education is noted, which means its health related influence $[16,33]$. Just this role of physical training determines the requirements to it. They imply ensuring of high health level as indicator of individual age viability. Refusal of old control criteria dictates searching new forms of assessment of students' physical fitness. Such forms of control shall comply with age standards and individual aspects of biological maturing of organism's morphological functional systems. Solution of this problem requires determination of individual's biological age. But there is no single

(c) Druz V.A., lermakov S.S., Nosko M.O., Shesterova L.Ye., Novitskaya N.A., 2017

doi:10.15561/18189172.2017.0201 criterion for its assessment, which would ensure solution of this problem. It results in different results of biological age assessments, made by different criteria.

New requirements to criteria for individual motor abilities' norms significantly changed the usage of the existing criteria for mean statistic evaluation of physical condition and physical fitness. Mean statistic criteria did not loose their significance. They shall be used as standard, in respect to which individual motor abilities and different criteria for biological age shall be found. Such criteria for physical health assessment permit to determine the components of physical condition and physical fitness, required for ensuring proper professional and domestic workability. The system of physical state and biological age multi-parametric assessment generates a peculiar barcode. Such code permits to find similarity of the compared object as well as to distribute indicators into groups of admissible communality (with pre-set tolerance of comparison) [5, 6, 22].

From the above said it follows that control over students' physical fitness shall be based on individual features of physical growth. Such features determine feasible level of physical fitness potentials. They ensure preservation of health, sufficient for professional and domestic workability [3, 31-33].

Hypothesis: effectiveness of specialists' professional training implies formation of the most optimal students' environment, in compliance with their intellectual and social conditions. Creation of such conditions in any organized collective is the most effective and fruitful process from economic point of view. For realization of this purpose it is necessary to have systemized certification of every collective member's individual potentials by their physical condition, physical fitness and physical state. It will permit to form maximally homogenous groups and determine homogeneity of educational medium's 
components as well as conditions of students' healthy life style. It will also ensure highly effective final result of future specialist's professional fitness. Individualization of students' potentials requires adequate individualization of educational medium's influence by all its components.

The purpose of the research: is to assess physical health and biological age of $1^{\text {st }} 2^{\text {nd }}$ year girl students, depending on their physical activity, as well as to work out system of control over students' health.

\section{Material and methods}

Participants: in the research $1^{\text {st }}$ and $2^{\text {nd }}$ year girl students $(n=120)$ participated. They were from Kharkov national medical university and National University, named after V.N. Karazin.

Organization of the research: we determined the girl students' biological age, physical health level. Motor activity level. All participants were being observed during two years in every academic semester (2014-2016).

Physical health level was assessed by express-method of G.A. Apanasenko [4]. Biological age was determined by method of G.A. Voytenko [11]. Physical activity was found with the help of questionnaire IPAQ [35]. Besides, questioning and anthropometrical measurements were fulfilled by M. Ya. Breitman [8].

Biological age was found with the help of "tests battery" of different complexity [11]. Speed of biological ageing was determined by the following stages: on the first stage actual biological age of an individual was found on the base of clinical biological indicators; than, by calendar age, his/her proper value of biological age was determined; after it - comparison of proper and actual biological age was fulfilled. The received results were presented in normalized space. Deviation from proper biological age was measured in portions of sigmal deviations from the found norm.

Physical fitness's influence on organism's viability potential was assessed by registration of girl students' physical activity in regime of their working day.

Girl students' physical activity was evaluated with standardized questionnaires (Global Physical Activity Questionnaire - GPAQ or International Physical Activity Questionnaire - IPAQ). Data processing implied calculation of energy losses in physical work, i.e. the value of metabolic equivalent of task. The conducted calculations permitted to find physical activity levels. High level of physical activity corresponds to one of two criteria: intensive physical activity with energy losses, corresponding to 1500 meters/minute in a day, during three or more days a week; or seven days with combination of walk with energy losses of not less than 3000 meters (minimum)/ week.

Moderate level of physical activity (corresponds to one of three criteria): three or more days a week of energetic physical activity (20 minutes a day); five or more days a week of moderate physical activity, or walking during 30 minutes a day; five or more days a week with combination of walking from moderate to intensive with energy losses of not less than 600 meters/ minute in a week.
Statistical analysis was fulfilled with the help of Excel program.

\section{Results}

We have evaluated significance of physical fitness as a regulator of students' required level of viability It is explained by the fact that the reasons of human irresponsible attitude to own health are: absence of knowledge about physical growth of own organism; non observation of healthy life activity conditions; absence of skills in feasible diagnostic and physical state correction methods. Regulation implies increase or decrease of influence of the factor, which is regarded as regulator of certain balanced state. With it, it is necessary to consider: the range of regulation (its fluctuations in respect to balanced condition); the level of stable state. Such state reflects potential of current viability. Besides, it reflects duration of regulation regime's deviation from initial stable state. Violation of these conditions results in desynchronizing of morphological functional formations' inter-support and weakening of organism's viability (too early biological ageing). Actually potential of balanced state's operative adaptation plays the role of compensatory mechanism, which preserves organism's balance in unstable state. It should be also considered that physical fitness level is not the only compensatory factor of balance state's preservation. Separately it is necessary to pay attention to equity demand in potential energy, which is spent for other components of operative adaptation compensation.

When determining girl students' biological age, we found that the range of variations was 9 years to each side from biological age norm. The ranked assessment of health was determined by remoteness from population standard. The structure of it is shown in fig. 1.

I and V ranks' students shall be regarded as having threatening health condition. There were four variants of biological age determination, which differed by complexity and were used depending on opportunities of laboratory. The presented here range of biological age variation relates to 2010 . The same researches in 2015 and 2016 showed reduction of biological age general indicator to the side of slowing. It reflects weakening of organism's resistance and acceleration of its wear out. It can be assumed that in this case important role is played by worsening of social factor of population's life.

We also analyzed separate aspects of physical activity. In fig. 2 we present the data of physical activity in working day and day off. The quantity of the tested was 21 girl students.

In fig. 3 we give distribution of time, spent for fulfillment of intensive or moderate physical activity in free time.

Assessment of physical activity of Kharkov national university, named after V.N. Karazin girl students showed that $71 \%$ of them have hyperkinesias.

The study of students' physical activity showed characteristic for most of them hyperkinesias. Analysis of time distribution into different activities during 
$\mathrm{N}$, frequency

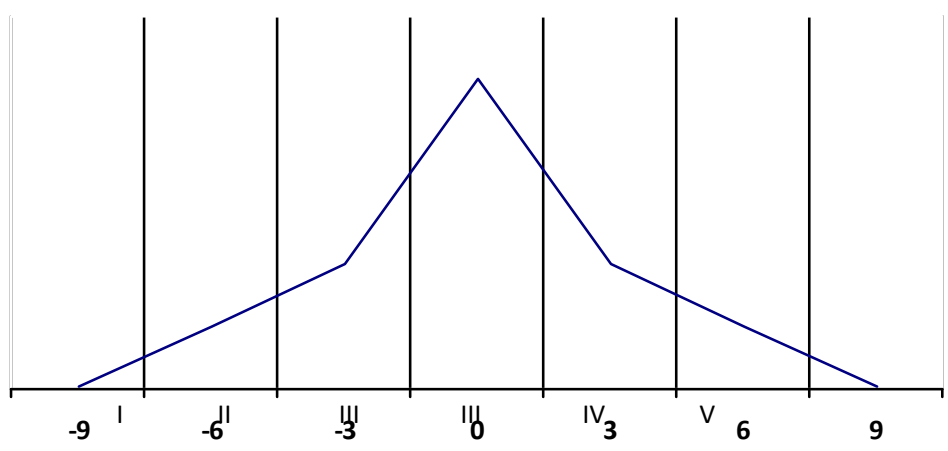

Fig. 1. Histogram of ranked assessment of biological age: I-V -rank.

Deviations in equities $\sigma$

I rank is maximally slowed growth.

II rank reflects moderate delaying of growth.

III rank - corresponds to zone of functionally optimal biological growth.

IV rank reflects zone of moderate forestall of biological growth.

$V$ rank means extremely accelerated forestall of biological growth $(-9,-6,-3,0,3,6,9)$ deviations of biological age from passport age in years.

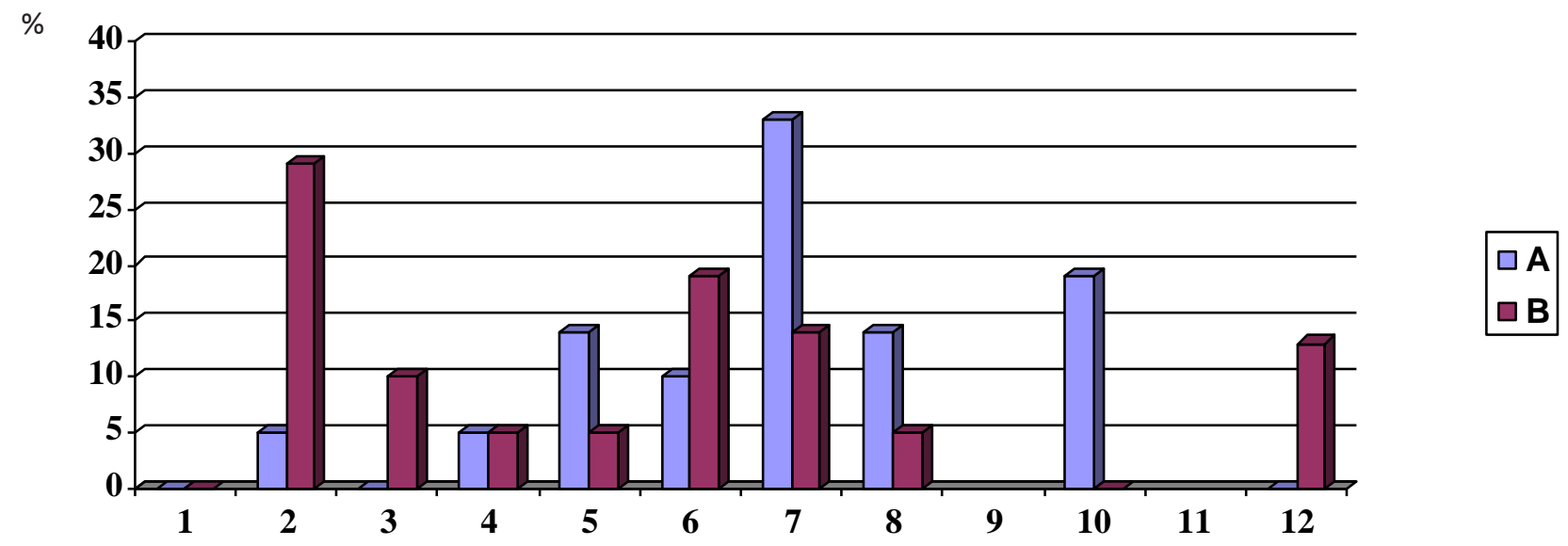

Fig. 2. Sitting hours in working day and day off: A - working day; B - day off; $t$ - time in hours; on X-axis - percents from the number of participants.

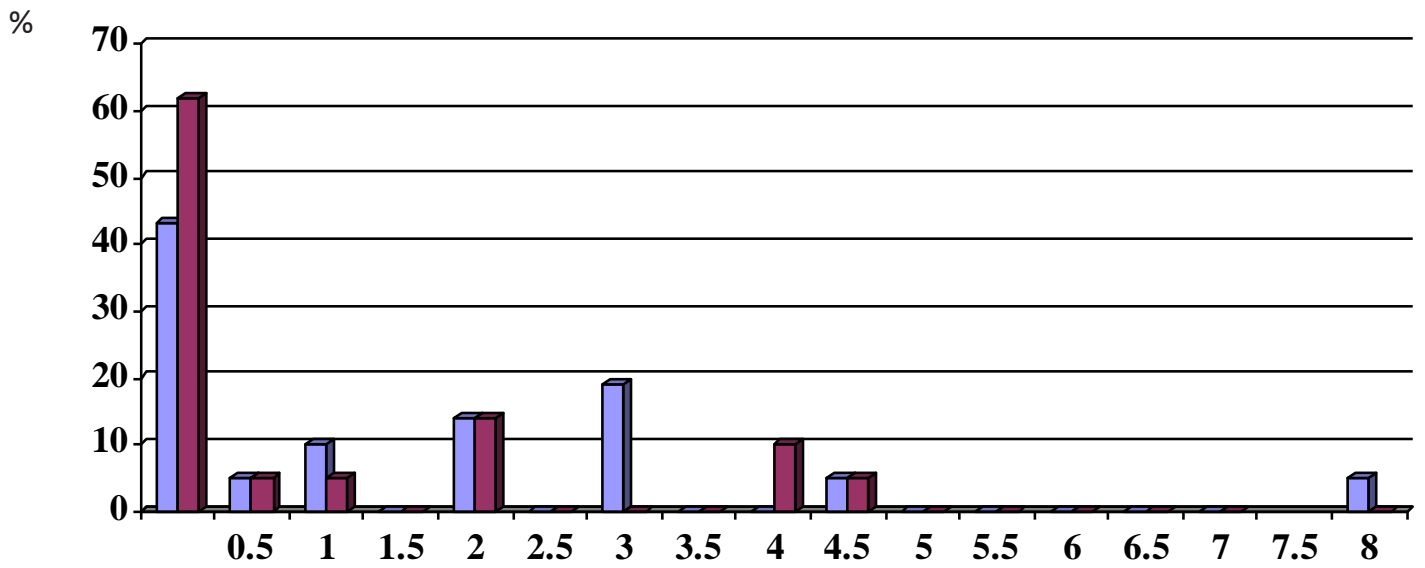

Fig. 3. Quantity of hours in free time, spent for intensive or moderate physical activity: $t$ - hours; $D$ - no physical activity; I - intensive; U - moderate. 
working day and in day off shows extremely high time deficit, which exceeds day limit by 3-4 hours. It results in compensatory time saving at the cost of its physical activity, rest and sleep as well as reduction of time for home task. In its turn it reduces the quality of professional training and accelerated weakening of physical potential of girl students' organism's viability. Generalized assessment of girl students' somatic health was fulfilled by sum of five indices (method of G.A. Apanasenko) (see table 1).

We tested physical health in 41 girl students of Kharkov national medical university. No girls, having high level of physical health, were found (see fig. 4).

Besides, we found aerobic threshold of energetic potential, below which disorders in different organism's functional systems become possible. It results in formation of endogenous risk factors and beginning of chronic pathological process. Such threshold is called "dangerous" level of somatic health. It can be evaluated quantitatively, in indicators of maximal energetic potential (MEP) or maximal oxygen consumption per $1 \mathrm{~kg}$ of body mass (MOC). It can also be presented in indirect indicators: physical workability, general endurance or health levels. Safe health level includes high and above average physical health levels. Only $7 \%$ of girl students related to this level. The rest 93\% were at the border of “dangerous" level. From this level endogenous risk factor can start to form and bring to pathological processes of definite nosological form. Quantitative characteristic of safe health level for $1^{\text {st }}-2^{\text {nd }}$ year girl students by MOC indicators was $33 \mathrm{~mol} / \mathrm{min} / \mathrm{kg}$; ergometer load power - 2 $\mathrm{W} / \mathrm{kg}$; time of $2 \mathrm{~km}$ distance covering shall be not more than 10 minutes $30 \mathrm{sec}$. In points it corresponds to level higher than 11. Express assessment of physical health by G.A. Apanasenko permits to detect "weak points" in organisms of the tested. Results of physical health testing in 41 girl students of Kharkov national medical university are given in table 2.

Mean statistic indicators of group body mass index was within norm $\left(18,50-24,99 \mathrm{~kg} / \mathrm{m}^{2}\right)$. However, individual values of body mass index in $5 \%$ of girl students have insignificant defect. In $2 \%$ girl students,

Table 1. Scale of assessment of physical health for women

\begin{tabular}{|c|c|c|c|c|c|}
\hline \multirow[t]{2}{*}{ Indicators } & \multicolumn{5}{|c|}{ Result in points } \\
\hline & Low & Below average & Average & Above average & High \\
\hline \multirow{2}{*}{$\begin{array}{l}\text { Body mass index / } \\
\text { (height) }{ }^{2} \mathrm{~kg} / \mathrm{m}^{2}\end{array}$} & -2 & -1 & 0 & -1 & -2 \\
\hline & $\leq 16,9$ & $17,0-18,0$ & $20,1-25,0$ & $25,1-28,0$ & $\leq 28,1$ \\
\hline \multirow{2}{*}{$\begin{array}{l}\text { Life index VCL /body } \\
\text { mass. mol/kg }\end{array}$} & -1 & 0 & 1 & 2 & 3 \\
\hline & $\leq 40$ & $41-45$ & $46-50$ & $51-56$ & $\leq 57$ \\
\hline \multirow{2}{*}{$\begin{array}{l}\text { Power index - hand's } \\
\text { strength /body mass \% }\end{array}$} & -1 & 0 & 1 & 2 & 3 \\
\hline & $\leq 40$ & $41-50$ & $51-55$ & $55-60$ & $\leq 61$ \\
\hline \multirow{2}{*}{$\begin{array}{l}\text { Time of HBR restoration } \\
\text { after } 20 \text { squats up to } 30 \\
\text { sec. min, sec. }\end{array}$} & -2 & 1 & 3 & 5 & 8 \\
\hline & $\geq 3$ & $2-2,59$ & $1,30-1,29$ & $1,0-1,28$ & $\geq 0,59$ \\
\hline Robinson's index. HBR x & -2 & -1 & 0 & 3 & 5 \\
\hline BP syst. / 100 conv.un. & $\geq 111$ & $95-110$ & $85-94$ & $70-84$ & $\geq 69$ \\
\hline Total points & $\leq 3$ & $4-6$ & $7-11$ & $12-15$ & $\leq 16-18$ \\
\hline
\end{tabular}

Notes: kg - kilograms; body length - meters; VCL - vital capacity of lungs; mol - milliliter; HBR - heart beats rate; BP syst. - systolic blood pressure, to be measured in milliliters of mercury column.

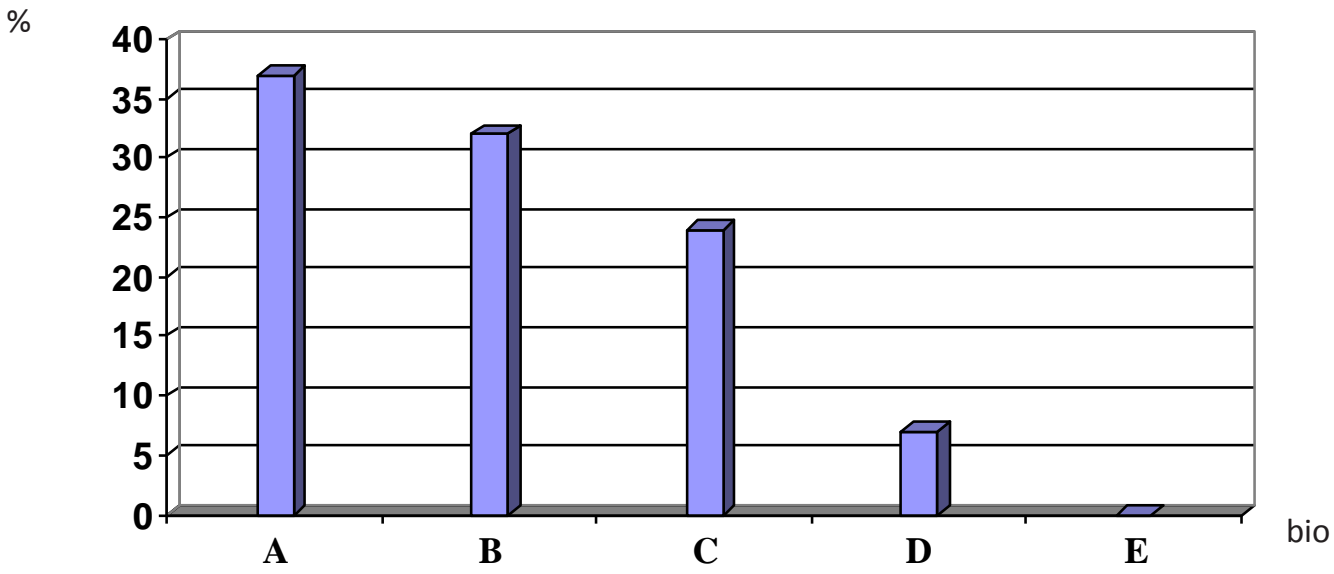

Fig. 4. Distribution $f$ physical health level in percents (\%) of 41 Kharkov national medical university girl students: $A$ -low; B - below average; C - average; D - above average; E - high;; Bio - biological level of health. 
body mass index corresponded to pre-obesity level. The rest 93\% girl students corresponded to normal level. Life index (reflecting external breathing function) determines ratio of lungs' vital capacity (VCL) to body mass. This indicator is less than norm in 5 girl students $(11 \%)$. Group power index was significantly lower than norm. Robinson's index (reflecting efficiency of cardio-vascular system's work) was within norm in the whole group. Restoration index (by test of Martinet-Kulishevskiy) exceeds upper limit of norm more than by 1.5 minute in $30 \%$ of the tested.

We analyzed indicators of girl students' biological age by five-rank scale in respect to their calendar age. We found that $54 \%$ girl students are in the $3^{\text {rd }}$ rank. It corresponds to the norm of population standard. Accelerated ageing was detected in 15 girl students from 43 (35\%). 9\% and 2\% of girl students were in second rank. The structure of such distribution is shown in fig. 5 .

Calendar age of the tested girl students is $17,6 \pm 0,3$ years. Group biological age is $23,2 \pm 0,7$ years. It exceeds population norm by 6 years.

The fulfilled factorial analysis of the received data permitted to find the structure of students' physical health integral indicators' structure. We found three main factors, which contributed $69.3 \%$ to general dispersion of sample (see table 3, fig. 6). The first factor (27,6\%) included body mass index and Robinson's index. The second factor $(21,2 \%)$ included indicators of students' biological age and life index. The structure of third index $(20,5 \%)$ included indicators of power index and restoration time after standard dozed load by test of Martine- Kushelevskiy.

\section{Discussion}

The regarded period of student's age is characteristic by the fact that vegetative reactions' level is high; assessment of interceptive and proprioceptive information about organism's physical condition and all main mechanisms of motor regulation have been practically completely formed. Characteristic feature of this girls' period is high sensitivity to fatigue. In the whole it is a period of physical strength peak, providing all requirements, necessary for growing organism are ensured. Organism's resistance is maximal. In this age girls have rather good physical fitness; they can successfully train and master exercises

Table 2. Indicators of $1^{\text {st }}-2^{\text {nd }}$ year girl students' physical health (KNMU)

\begin{tabular}{ll}
\hline Indicators & $\mathbf{x} \pm \mathbf{m}$ \\
\hline Body mass index $\mathrm{kg} / \mathrm{m}^{2}$ & $20,9 \pm 0,3$ \\
Life index mol/kg & $55,6 \pm 1,1$ \\
Power index \% & $28,2 \pm 1,1$ \\
Robinson's index, conv.un. & $86,6 \pm 32$ \\
Time of HBR restoration after test of Martinet- & $95,6 \pm 5,1$ \\
Kushelevskiy, sec. & \\
\hline
\end{tabular}

$\%$

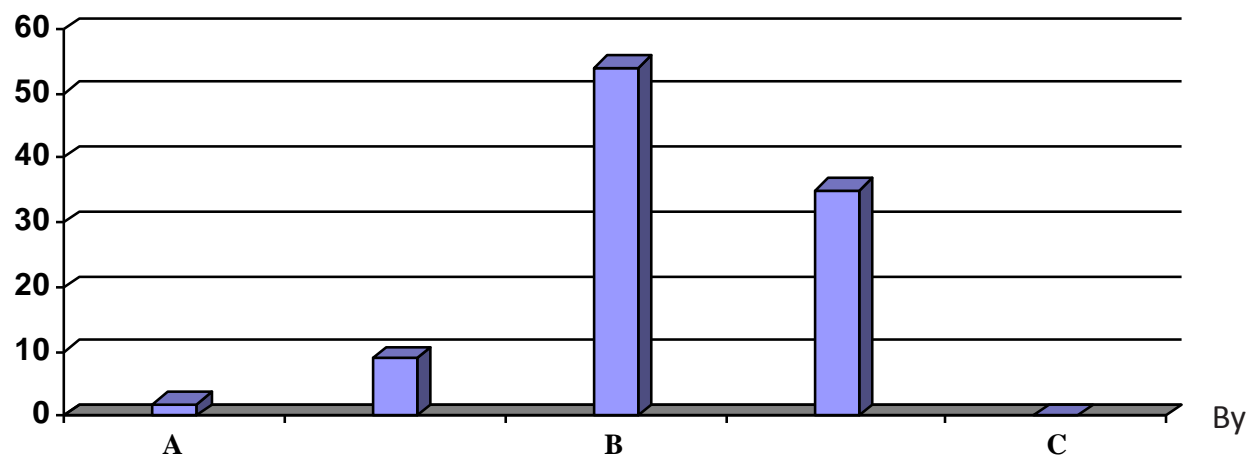

Fig. 5. Distribution of biological age in $\%$ of Kharkov national medical university girl students: By - biological age; A very slow process; B - corresponds to population standard; C- very quickly.

Table 3. Factorial structure of integral indicators of $1^{\text {st }}-2^{\text {nd }}$ year girl students

\begin{tabular}{llll}
\hline Description of indicators & I factor & II factor & III factor \\
\hline Body mass index $\mathrm{kg} / \mathrm{m}^{2}$ & 0,77 & & \\
Life index mol/kg & $-0,84$ & & \\
Power index \% & & 0,78 & \\
Robinson's index, conv.un. & & $-0,82$ & $-0,82$ \\
Time of HBR restoration after test of & & 0,75 \\
Martinet-Kushelevskiy, sec. & & \\
\hline
\end{tabular}




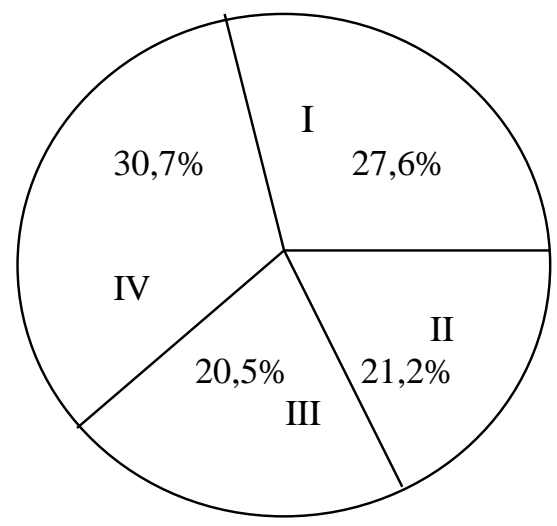

Fig. 6. Diagram of structure of $1^{\text {st }}-2^{\text {nd }}$ year girl students' physical health's integral indicator;

I - factor of general dispersion (body mass index and Robinson's index);

II - factor of general dispersion (biological age and life index);

III - factor of general dispersion (power index and restoration time after load by Martinet-Kushelevskiy's test);

IV - factor of general dispersion (medium components, which were not taken into account).

with complex coordination. In respect to motor skills' development, increase of all muscular groups' strength is observed and motor quickness reaches maximal value. Progress and development of general endurance and dexterity is continuing. Comparing with adolescents' age weakening of flexibility is observed [25].

Sustaining of required general physical fitness for obtaining the required health related effect from physical culture practicing requires attentive attitude and control over anatomic physiological parameters of woman's organism [17]. The embedded in this period health and healthy life style practicing is the basis of further young people's self-organization, their active working longevity, ability for procreation and building family; social and creative activity [18]. Health ensures organism's adaptation to changing internal and external medium; preserves and expands organism's functional systems' reserves. That is why organism's adaptation potentials can be regarded as a measure of health. Well organized control over health ensures possibility of pre-nosological diagnostic and timely prophylaxis $[9,14]$.

However, at present students' health troubles pedagogic community. In specialists' opinion students belong to category of population with increased risk of diseases. At present time we observe steady reduction of indicators of organism's functional systems and students' physical workability from junior to senior years of study [1, 24].

In assessment of physical health organism's biological ageing is an important criterion. It is rather accurate and early indicator of pre-morbid states, quantitative characteristic of health and effectiveness of adaptation to unusual ecological and professional conditions $[7,10,15$, 27].

For growing organism delaying and advancing of biological age is an indicator of health's worsening. Two persons of the same calendar age can greatly differ by intensity of physiological functions' wear out. Determination of students' biological age can facilitate their re-orientation on healthy life style. In its turn it will facilitate more successful professional training [20, 2830].

By data of different authors students' biological age is in average 30-35 years. At present the discrepancy between biological and passport age is 10-15 years. 15-20 years ago this indicator was $4-5$ years $[19,21]$.

Study of the problem of physical training individualization brings to demand in regarding the components, which determine it: physical health; healthy life style; social-domestic norms of life activity environment. To regard any component as separate would not be a correct decision [12, 26, 36, 37].

For long time not solved problem of norm's assessment have not permitted to form the conception "physical health" itself. This problem was solved only by introduction of indicative semantic spaces with single measure of the used attributes measurements [6, 22]. It permitted to find common features, intrinsic to normal human condition. On the base of the received results there appears possibility to assess individual aspects of norm's manifestation [2]. Commensurability of all components is realized in parts of sigmal deviation. In this case any deviation both to hypo or hyper sides from balanced state of inter-conditioned relations are quantitative and qualitative indicators of health worsening [13].

One of regulating factors of required students' viability sustaining is quantitative and qualitative structure of students' physical fitness. It determines demand in individualization of this process.

\section{Conclusions}

1. Physical health is an indicator of students' viability. That is why organization of mass health related physical culture requires the following: consideration of physical condition's individual norm; initial level of physical fitness; feasible physical loads. Controlling students' physical condition, it is necessary to register individual 
aspects of their development and corresponding to them individual norm of students' state. The received control data shall be accumulated in data base for all period of students' study for analyzing, if required.

2. Mass health related physical training in higher school shall be based on appropriate volume of motor functioning, its orientation and intensity. All these shall correspond to age level of students' individual physical condition. The structure of group physical culture training shall be based on a number of indicators, reflecting homogeneity of group members. They are: load volume; arsenal of means; regime of load's distribution during day; individual features of students' physical condition; current physical condition; initial fitness. On the base of these criteria of contingent's similarity the size of group is determined. Interest in the offered physical activity shall be additional and compulsory criterion of group's formation. With it, the limits of the required minimal and maximal physical fitness for definite age and shall be determined. It is dictated by individual approach to training.
3. For effective coordination of mass health related physical culture it is necessary to find means and keep records of required physical fitness. Then, on the base of the accumulated data, it is necessary to determine regional and population age norms for mass health related physical culture. It will permit to create single coordinated system of this process's provisioning.

4. Students' physical health is an integral indicator of their viability. It includes: physical condition, physical fitness, current physical condition. It is the essence of physical culture, which, in its turn, is an integral part of general culture of society. That is why physical fitness and physical health can not compensate reduction of other factors' requirements, which are components of students' healthy life style final result. For cultivation healthy life style in students it is necessary to observe the requirements of all its components. Violation of any component's requirements will fail final result.

\section{Conflict of interests}

The author declares that there is no conflict of interests.

\section{References}

1. Agadzhanian NA, Baevskij RM, Bersen'eva AP. Problemy adaptacii i ucheniia zdorov'ia [The problems of adaptation and discipline of health], Moscow: RUDN Publ.; 2006. (in Russian)

2. Azhippo AIu, Pugach IaI, Druz' VA, Shernovnikova IaV. Opredelenie biologicheskogo vozrasta v razlichnye periody ontogeneza cheloveka [Determination of biological age in different periods of human ontogeny]. Slobozhans'kij naukovo-sportivnij visnik, 2015;4 (48):7-14. (in Russian)

3. Azhippo AIu, Pugach IaI, Zherkovnikova IaV. Problema opredeleniia biologicheskogo vozrasta $\mathrm{v}$ sisteme ocenki fizicheskogo razvitiia i donozologicheskoj diagnostiki konstitucionnykh zabolevanij [The problem of biological age determination in system of physical condition's assessment and pre-nosological diagnostic of constitutional diseases]. Slobozhans'kij naukovo-sportivnij visnik, 2015;3 (47): 7-12. (in Russian)

4. Apanasenko GL, Popova LA. Medicinskaia valeologiia [Medical valueology], Rostov on Don: Phoenix; 2000. (in Russian)

5. Artem'eva GP, Pugach IaI, Druz' VA. Problemy adaptacii $v$ strukture nauchnykh issledovanij sistemy olimpijskogo obrazovaniia [The problems of adaptation in structure of scientific researches of Olympic education system], Kharkiv: HGAFK; 2014. (in Russian)

6. Ashanin VS, Pugach IaI. Postroenie semanticheskikh prostranstv dlia opisaniia psikhosomaticheskoj deiatel'nosti cheloveka $v$ ekstremal'nykh usloviiakh [Construction of semantic spaces for description human psycho-somatic functioning in extreme conditions], Kharkiv: HGAFK; 2014. (in Russian)

7. Belozercev LM. Metody opredeleniia biologicheskogo vozrasta $i$ umstvennoj $i$ fizicheskoj rabotosposobnosti [Methods of biological age, mental and physical workability determination], Perm: Perm State Medical Academy; 2000. (in Russian)

8. Brejtman MIa. Tablicy dlia klinicheskoj antropometrii [Tables for clinical anthropometry], Leningrad; 1926. (in Russian)
9. Bushev IuB, Dovzhenko LP. K probleme raspredeleniia studentov na gruppy dlia zaniatij fizicheskogo vospitaniia [On the problem of students' distribution into groups for physical education]. Fizkul'tura $v$ profilaktike, lechenii $i$ reabilitacii, 2004;3 (7):34-37. (in Russian)

10.Vojtenko VP. Biologicheskij vozrast [Biological age]. In: Biologiia stareniia [Biology of ageing], Leningrad: Science; 1982. P. 102-115. (in Russian)

11. Vojtenko VP, Tokar' AV. Biologicheskij vozrast i prognozirovanie prodolzhitel'nosti zhizni [Biological age and prognostication of longevity]. In: Gerontologiia $i$ geriatriia [Gerontology and geriatrics], Kiev; 1979. P. $34-$ 43. (in Russian)

12.Druz VA. Analiz obshchikh principov funkcional'nykh otnoshenij sistem organizma $v$ dinamike. Dokt. Diss. [Analysis of general principles of organism's functional systems' relations in dynamic Doct. Diss.], Kiev; 1987. (in Russian)

13.Druz' VA, Buren' NV, Pugach IaI. Obzornyj analiz po probleme "Teoretiko-metodologicheskie osnovy postroeniia sistemy massovogo kontrolia $i$ ocenki urovnia fizicheskogo razvitiia $i$ sostoianiia, fizicheskoj podgotovlennosti razlichnykh grupp naseleniia" [Overview of problem "Theoretical methodological principles of mass control system and physical condition assessment of different population groups"], Kharkiv: HGAFK; 2014. (in Russian)

14.Zambrdzhidskij ON, Badukova NL, Katkovskaia MV. Ekspress-ocenka urovnia individual'nogo zdorov'ia u studentov [Express-assessment of students' individual health]. Zdorov'e i okruzhaiushchaia sreda, 2007;9:815-817. (in Russian)

15.Kishuk AA. Biologicheskij vozrast i starenie [Biological age and ageing], Moscow: GEOTAR Media; 2008. (in Russian)

16.Krucevich T. Ekspres kontrol' fizichnoi pidgotovlenosti ditej ta pidlitkiv $\mathrm{v}$ umovakh fizkul'turno-ozdorovchikh zaniat' [Express control of children's and adolescents' physical fitness in conditions of health related physical culture trainings\}. Teoriia $i$ metodika fizichnogo vikhovannia $i$ sportu, 2007;1:64-69. (in Ukrainian)

17.Krucevich TIu, Bezverkhnia GV. Rekreaciia u fizichnij kul'turi riznikh grup naselennia [Recreation in physical 
culture of different population strata]. Kiev: Olympic Literature; 2010. (in Ukrainian)

18.Lotonenko AV, Gostev GR, Grigor'ev OA. Fizicheskaia kul'tura i zdorov'e [Physical culture and health]. Moscow: Euroschools; 2008. (in Russian)

19.Loshickaia TI. Biologicheskij vozrast i tempy stareniia organizma studentov [Biological age and ageing temps in students' organisms]. Pedagogics, psychology, medicalbiological problems of physical training and sports, 2010;7:50-52.

20.Pozdniakov NM, Proshchaev AN. Sovremennye vzgliady na vozmozhnost' ocenki biologicheskogo vozrasta $\mathrm{v}$ klinicheskoj praktike [Modern view on biological age assessment in clinical practice]. Fundamental'nye issledovaniia, 2011;2:17-22. (in Russian)

21.Prikhod'ko SI. Sravnitel'nyj analiz tempov stareniia iunoshej i devushek studencheskogo vozrasta [Comparative analysis of student's age boys and girls' ageing temps]. Pedagogics, psychology, medical-biological problems of physical training and sports, 2012;6:104-106.

22.Pugach IaI. Osnovnye polozheniia postroeniia semanticheskogo prostranstva dlia uporiadochennogo predstavleniia rezul'tatov issledovaniia [Main principles of semantic space construction for ordered presentation of research's results]. IX mezhdunarodnaia nauchnoprakticheskaia konferenciia «Aktual'nye voprosy iz mira nauki» [IX International scientific-practical conference "Current problems of the world of science"]. Sofia: «Byal Grad - BG»; 2013;39. P. 5-13. (in Russian)

23.Sedov LI. Metody podobiia i razmernosti v mekhanike [The methods of similarity and dimensionality in mechanics], Moscow: Science; 1984. (in Russian)

24.Tkachenko GV, Veritel'nikova IuA, Stratij NV. Uroven' fizicheskogo zdorov'ia studentov kak klinikofiziologicheskaia osnova i motivaciia sostavliaiushchaia fizicheskogo vospitaniia v VUZe [Students' physical health as clinical-physiological ground and motivational component of physical education in HEE]. Moloda sportivna nauka Ukraini, 2015;19(4):211-215. (in Russian)

25.Chernenko E., Gureeva A. Influence of employment by various kinds of improving aerobics on a level of physical readiness of girls of 18-20 years. Pedagogics, psychology, medical-biological problems of physical training and sports, 2010;3:145-147.

26.Shmidt-Niel'sen K. Razmery zhivotnykh: pochemu oni tak vazhny? [Animals' sizes: why they are so important?], Moscow: World; 1987. (in Russian)
27.Collier-Harris CA, Goldman JDG. What educational contexts should teachers consider for their puberty education programmes? Educational Review. 2017;69(1):118-33.

28.Czerwinski F, Finne E, Kolip P, Bucksch J, Germany HSG. Individual and school level correlates of moderate to vigorous physical activity among school-children in Germany - a multi-level analysis. Bmc Public Health. 2015;15.

29.do Rego JTP, da Silva TAL, Medeiros RMV, Barboz RR, de Medeiros JA, Dantas PMS, et al. Nutritional knowledge and anthropometric status of university athletes. Rev Bras Med Esporte. 2015;21(6):447-50.

30.Dornelas LF, Duarte NMC, Morales NMO, Pinto RMC, Araujo RRH, Pereira SA, et al. Functional Outcome of School Children With History of Global Developmental Delay. Journal of Child Neurology. 2016;31(8):1041-51.

31.Kalina RM, Jagiello W, Chodala A. The result of "testing fights in a vertical posture" as a criterion of talent for combat sports and self-defence - secondary validation (part I: the reliability). Archives of Budo Science of Martial Arts and Extreme Sports. 2015;11:229-38.

32.Klimczak J, Kalina RM, Jagiello W. Fun forms of martial arts in diagnosing and reducing aggressiveness - mental effects of a one-day course for Polish animators of sport. Health and Martial Arts in Interdisciplinary Approach. 2015:187-9.

33.Kusnierz C, Cynarski WJ, Gorner K. Social reception and understanding of combat sports and martial arts by both school students and adults. Ido Movement for CultureJournal of Martial Arts Anthropology. 2017;17(1):30-7.

34.Lee PH, Macfarlane DJ, Lam T, Stewart SM. Validity of the international physical activity questionnaire short form (IPAQ-SF): A systematic review. International Journal of Behavioral Nutrition and Physical Activity. 2011;8(1):115120.

35. Oyhenart EE, Lomaglio DB, Dahinten SLV, Bejarano IF, Herraez A, Cesani MF, et al. Weight and height percentiles calculated by the LMS method in Argentinean schoolchildren. A comparative references study. Annals of Human Biology. 2015;42(5):439-46.

36.Pardo BM, Bengoechea EG, Clemente JAJ, Lanaspa EG. Motivational Outcomes and Predictors of Moderateto-Vigorous Physical Activity and Sedentary Time for Adolescents in the Sigue La Huella Intervention. Int J Behav Med. 2016;23(2):135-42. 
Information about the authors:

Druz V.A.; http://orcid.org/0000-0002-4628-6791; valeriidruz@gmail.com; Kharkov State Academy of Physical Culture; Klochkovskaya str. 99, Kharkov, 61022, Ukraine.

lermakov S.S.; http://orcid.org/0000-0002-5039-4517; sportart@gmail.com; Kazimierz Wielki University; Sport str. 2, of.209, 85-064 Bydgoszcz, Poland.

Nosko M.O.; http://orcid.org/0000-0001-9903-9164; pryimalnya214chnpu@meta.ua; Chernigiv National T.G. Shevchenko Pedagogical University; Str. Polubotko Getman, 53, Chernigov, 14000, Ukraine.

Shesterova L.Ye.; http://orcid.org/0000-0001-6149-1980; shesterova1@mail.ru; Kharkov State Academy of Physical Culture; Klochkovskaya str. 99, Kharkov, 61022, Ukraine.

Novitskaya N.A.; http://orcid.org/0000-0001-5412-8016; Novisha71@mail.ru; Kharkov State Academy of Physical Culture; Klochkovskaya str. 99, Kharkov, 61022, Ukraine.

Cite this article as: Druz V.A., Iermakov S.S., Nosko M.O., Shesterova L.Ye., Novitskaya N.A. The problems of students’ physical training individualization. Pedagogics, psychology, medical-biological problems of physical training and sports, 2017;2:51-59. doi:10.15561/18189172.2017.0201

The electronic version of this article is the complete one and can be found online at: http://www.sportpedagogy.org.ua/index.php/PPS/issue/archive

This is an Open Access article distributed under the terms of the Creative Commons Attribution License, which permits unrestricted use, distribution, and reproduction in any medium, provided the original work is properly cited (http://creativecommons.org/licenses/by/4.0/deed.en).

Received: 12.02 .2017

Accepted: 25.02.2017; Published: 30.04.2017 